\title{
Transformações na cerâmica kadiwéu em Mato Grosso do Sul, Brasil
}

\author{
Transformations in kadiwéu ceramic in Mato Grosso do \\ Sul, Brazil
}

\author{
Gilberto Luiz Alves ${ }^{1}$ \\ Selma Maria Rodrigues ${ }^{1}$
}

DOI: http://dx.doi.org/10.20435/tellus.vi44.700

Resumo: Este artigo tem por objeto as transformações ocorridas na cerâmica Kadiwéu em Mato Grosso do Sul. Objetivando analisá-las historicamente, foram essenciais categorias teóricas tomadas de Berta Ribeiro. O levantamento de dados empíricos explorou fontes primárias como relatos de antropólogos e naturalistas que palmilharam aldeias Kadiwéu desde a década de 1880. Imagens fotográficas e desenhos, além de observações sistemáticas em situações de trabalho, tanto em aldeia Kadiwéu quanto em postos de comercialização de artesanato, contribuíram para o entendimento do processo de produção e ornamentação de artefatos cerâmicos. Fontes secundárias foram buscadas em pesquisas realizadas desde o início do século XXI. Entre as conclusões foram constatadas: a) a permanência no tempo das técnicas e instrumentos de trabalho usados pelas ceramistas; b) e a transformação dos antigos utensílios em mercadorias, determinante para as mudanças das funções das peças, das suas formas e dimensões, bem como para aligeirar o processo de produção.

Palavras-chave: desenvolvimento regional; artesanato indígena; arte oleira.

Abstract: The purpose of this article are the transformations occurred in Kadiwéu ceramic in Mato Grosso do Sul. In order to analyze them historically, were essential the theoretical categories taken from Berta Ribeiro. The survey of empirical data explored primary sources such as reports of anthropologists and naturalists who treaded Kadiwéu villages since the 1880s. Photographic images and drawings, besides systematic observations in work situations, as much in Kadiwéu village as in craft trades, contributed to the understanding of the process of production and ornamentation of ceramic artifacts. Secondary sources have been sought in researches which have been conducted since the beginning of the 21st century. Among the conclusions were found: a) the permanence in time of the techniques and instruments of work used by

${ }^{1}$ Universidade Anhanguera - UNIDERP, Campo Grande, Mato Grosso do Sul. Brasil. 
the potters; b) and the transformation of the old utensils into commodities, determinant for the changes of the functions of the pieces, their forms and dimensions, as well as for the lightening of the production process.

Keywords: regional development; indigenous crafts; potter art.

\section{INTRODUÇÃO}

Este artigo tem por objeto as transformações ocorridas na cerâmica Kadiwéu em Mato Grosso do Sul. Essas mudanças denotam, como em qualquer produto do trabalho humano, que a cerâmica indígena vem se adaptando às transformações mais gerais que operam sobre a existência material da etnia. Ou, para resumir, elas são históricas.

Ao longo do tempo, ao sabor das transformações que marcaram a vida das comunidades indígenas como um todo, mudaram as finalidades norteadoras da produção de peças cerâmicas. Esse reconhecimento impele à consideração de importante noção aristotélica veiculada em Política: as coisas se definem pelas funções que exercem no todo (ARISTÓTELES, 1988). Portanto, se muda a totalidade, mudam as funções das partes que a integram. E quando as funções das coisas mudam, tem-se o indicador de que elas se tornaram outras coisas. Daí a necessidade de novas definições que traduzam suas recentes formas de ser. Esse fato se patenteia nas diversas manifestações da cerâmica indígena em Mato Grosso do Sul.

Acentue-se que, atualmente, três são as etnias oleiras na região: Kadiwéu, Terena e Kinikinau. Os principais polos de produção são as aldeias Kadiwéu, em especial Alves de Barros, localizadas em sua reserva no município de Porto Murtinho; a Aldeia Cachoeirinha, em Miranda, que concentra o grosso da produção das artesãs Terena, e a Aldeia São João, em Porto Murtinho, onde vive um contingente Kinikinau que, pela transferência de algumas famílias para a recém-fundada Aldeia Mãe Terra, em Miranda, vem gerando outro polo de produção neste local.

Ao longo do tempo, registros de viajantes analisaram a vida das etnias na região hoje correspondente a Mato Grosso do Sul. Alguns, em especial os naturalistas e antropólogos, também descreveram o processo de produção de peças cerâmicas, sobretudo entre os Kadiwéu (SMITH, 1922; BOGGIANI, 1945; LEVISTRAUSS, 1957; RIBEIRO, 1980). Antigos registros sobre a cerâmica Terena são 
mais raros (OLIVEIRA, 1968; 1976). A atividade oleira dos Kadiwéu, dos Terena e dos Kinikinau vem merecendo diversas pesquisas recentes (SIQUEIRA JR, 1992; GODOY, 2001; GRAZIATO, 2008; 2011; GOMES, 2008; ALVES, 2014; 2017; 2020; CANAZILLES, 2013; SÁ; INAGAKI, 2014; KOMIYAMA, 2015; CHAVES, 2015).

As manifestações étnicas na cerâmica guardam suas peculiaridades em especial quanto à ornamentação. No geral, observa-se que permaneceram no tempo técnicas como o acordelado, entre todas as etnias, a exploração de recursos naturais como a hematita, entre os Terena, e a resina de pau-santo, entre os Kadiwéu, bem como o uso dos instrumentos de trabalho. Mas a escassez de alguns produtos, os deslocamentos das etnias no espaço e, mais recentemente, a produção para o mercado, têm impactado a resistência, a pintura, as dimensões e as funções das peças.

Na realização da pesquisa optou-se pelo delineamento histórico. Quanto à abordagem metodológica, em face do objetivo de analisar especificamente as transformações da cerâmica Kadiwéu, foram eleitas como fontes de dados empíricos os relatos de viajantes, de autoridades administrativas, de naturalistas e de antropólogos que circularam pela região. Alguns deles ilustraram detalhadamente o processo de produção de peças cerâmicas de origem indígena desde o final do século XIX e seus escritos se tornaram relevantes registros de épocas. Foram tomados como referências os de Herbert H. Smith (1922), naturalista norte-americano que descreveu a produção da cerâmica dessa etnia na década de 1880; de Guido Boggiani (1945), artista plástico italiano que, por duas vezes, esteve entre os Kadiwéu na década de 1890; de Claude Levi-Strauss (1957), antropólogo francês que visitou os Kadiwéu na década de 1930, e de Darcy Ribeiro (1980), que realizou estudos sobre essa etnia e com ela conviveu na década de 1940. As categorias que permitiram unificar a descrição do processo de produção da cerâmica foram tomadas de Berta Ribeiro (1988).

Quando necessárias, foram consultadas fontes secundárias decorrentes de pesquisas realizadas sobre a matéria recentemente. Esses trabalhos vêm crescendo em quantidade e não podem deixar de ser referidos os estudos de Siqueira Jr. (1992), Graziato (2008; 2011), Alves (2014; 2017), Sá e Inagaki (2014) e Komiyama (2015). Imagens, em especial fotos e desenhos, contribuíram para caracterizar elementos de transformações nas peças cerâmicas Kadiwéu ao longo do tempo. Observações sistemáticas em situação de trabalho, tanto na Aldeia 
Alves de Barros quanto em lojas de comercialização de artesanato, permitiram confirmar informações ou não, sobretudo quanto aos aspectos referentes à produção e ornamentação das peças.

\section{OS RAROS REGISTROS SOBRE A CERÂMICA INDÍGENA NO SUL DE MATO GROSSO ATÉ 1880}

Os registros relativos às etnias indígenas do sul de Mato Grosso anteriores à década de 1880 são de limitada importância para o objeto deste artigo. As análises, quando muito, tangenciam a cerâmica. Como quase sempre se referem aos Guaicuru, esclareça-se que os Kadiwéu são seus únicos remanescentes no sul de Mato Grosso atualmente.

A 5 de maio de 1791, enquanto realizava expedição científica pela Capitania de Mato Grosso, o naturalista Alexandre Rodrigues Ferreira dirigiu uma carta ao Capitão-General João de Albuquerque de Mello Pereira e Cáceres. Informava que os guaicuru não se fixavam. Em constante "corso" e já reconhecidos como índios cavaleiros, inclusive as mulheres cavalgavam. Por serem nômades, suas "palhoças" eram precárias, ao contrário das habitações "fixas" dos Guaná. Considerou a pintura corporal como a principal atividade artística da etnia. Os desenhos plasmavam-se na "pele" e envolviam "diversas listras e figuras". O "urucu" (Bixa orellana), a "tabatinga" e o "jenipapo" (Genipa americana) eram usados para pintar a "face", "as mãos e os pés, os lábios e as orelhas". Toda mulher ostentava na "perna um sinal que é o da marca do seu cavalo" (FERREIRA, 1974, v. 1, p. 79-80).

Um desenho, produzido como registro documental de sua expedição científica, ilustrou a aparência de uma negra cativa que vivia entre os Guaicuru. Vitória era o seu nome e fez o papel de intérprete entre índios e expedicionários. Ostentava tatuagem que reproduzia grafismos étnicos, além de outros adornos típicos desse povo. Sua "cabeça raspada" e o "topete longitudinal" eram indicativos de sua condição de casada (FERREIRA, 1974, v. 1, p. 82). 
Figura 1 - Vitória, negra cativa dos Kadiwéu, com pintura facia

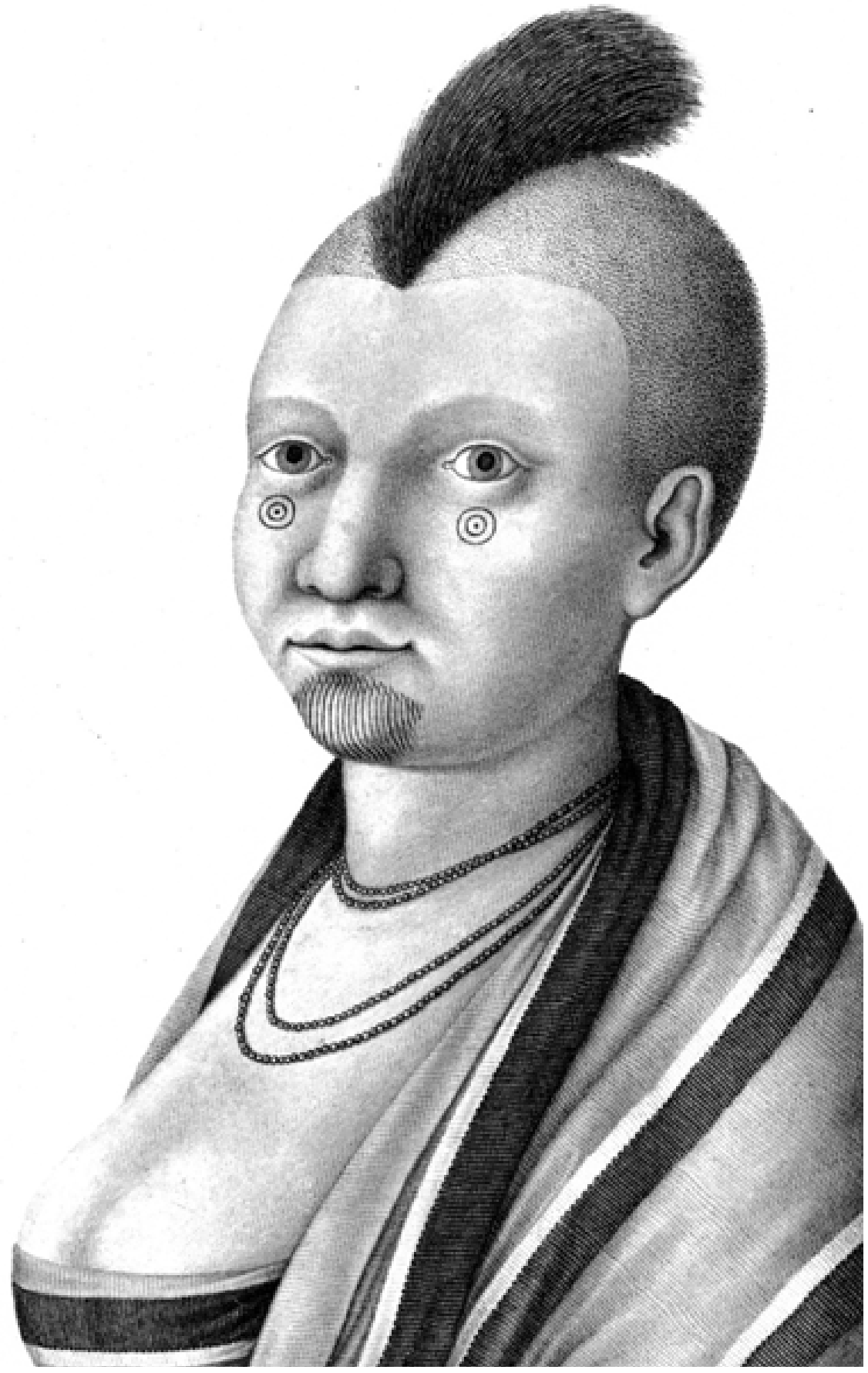

Fonte: Ferreira, 1971. 
Em 1795, Francisco Rodrigues do Prado, comandante do Presídio de Coimbra, se referiu à "nação guaicuru" como "errante" e não afeita ao "cultivo da terra". Habitava "as margens do Rio Paraguai" (PRADO, 2006, p. 21). Seus membros tinham "grande propensão para tecer" (PRADO, 2006, p. 31) e estava difundido entre eles o uso da pintura corporal. Observou que eles "Pintam todo o corpo com a tinta de duas frutas silvestres chamadas urucum e jenipapo; e na pintura guardam bastante simetria". Sem disfarçar a aversão, acrescentou que:

[...] as grossas tintas com que [as mulheres] se pintam, as fazem desagradáveis à nossa vista; mandam-se picar com espinhos na testa, formando linhas que principiam na raiz do cabelo e vêm acabar sobre as pálpebras dos olhos, na face e na barba, onde formam um xadrez, e dão logo com tinta de jenipapo, com o que se conservam toda a vida pintadas de cor cinzenta; e as donas também fazem nos braços uns quadrados, sofrendo em todas essas ocasiões cruéis dores. [...]. Trazem também debuxada a marca do seu cavalo; o que fazem ainda no próprio corpo. (PRADO, 2006, p. 29-30).

Ao discutir a divisão sexual do trabalho, o Comandante do Presídio de Coimbra fez um registro incomum. Disse que aos homens cabiam a caça, a pesca, a extração de "carandás e palmitos", o cuidado com os cavalos e os afazeres da "guerra". As mulheres "fiam algodão, tecem panos e cintas, fazem cordas, louça e esteiras" (PRADO, 2006, p. 34, grifo nosso). Portanto, segundo esse testemunho, as mulheres Kadiwéu já produziam peças cerâmicas no final do século XVIII. Porém, até o segundo terço do século XIX, os escassos registros produzidos por viajantes e estudiosos não reforçaram essa assertiva.

Em 1848, o Diretor Geral dos Índios da Capitania de Mato Grosso, Joaquim Alves Ferreira, produziu uma notícia que estimava a população dos "GuaicurúsCadiuéos" em torno de "850" indivíduos. Afirmou que ela conservava "vestígios do primitivo espírito altivo e belicoso dos seus antepassados" (FERREIRA, 2001, p. 17), bem como de "sua vagabunda vida" (FERREIRA, 2001, p. 31). Desde "Coimbra para baixo", os Kadiwéu circulavam pelas margens direita e esquerda do Rio Paraguai. Não se fixavam por muito tempo, daí o uso temporário de "tendas formadas de estacas e cobertas de esteiras e peles, verdadeiro arraial militar que em poucos momentos assenta-se e levanta-se". Viviam "da caça e da pesca" e criavam "bastante gado cavalar e algum lanígero". Permutavam 
"cavalos e algumas cordas e outras obras de embira por aguardente, machadinhas, facas, pano de algodão, fitas, chitas, baetas e prata para canudos com que fazem enfeites." (FERREIRA, 2001, p. 17). Quanto aos Guaná, eram sedentários e residiam "em aldeias mais ou menos populosas" ( $p . x x)$. Também viviam da caça e da pesca, "mas principalmente da carne de vaca e dos produtos de sua lavoura. Cultivam milho, mandioca, arroz, feijão, cana, batatas, hortaliça e igualmente todos os gêneros de agricultura do país" (p. xx). Referindo-se às suas manifestações artesanais, observou que "Fiam e tecem e tingem o algodão e a lã do que fazem ótimas redes, panos, cintos e suspensórios" (p. xx). As diferentes aldeias Guaná superariam o número de 2500 indivíduos, fora os 800 "Guanás-Kinikináos" (FERREIRA, 2001, p. 19). O Diretor Geral do Índios não fez nenhuma referência à cerâmica indígena, portanto.

Quase ao mesmo tempo, em 1840, Francis Castelnau transitou por Corumbá, Albuquerque e Forte Coimbra. Foram raras as referências à arte oleira indígena, mesmo existindo no entorno aldeias Kadiwéu, Guaná e Kinikinau. Ao se reportar aos Guaná afirmou que "fabricam vasilhas de barro" (CASTELNAU, 1949, p. 247). Sobre a aldeia dos "Quiniquinaus, tribo pertencente à mesma nação guaná, porém menos civilizada", não fez qualquer registro sobre a cerâmica (p. 248-9).

Em relação aos guaicuru, escreveu que a "indústria desses índios resume-se em redes e tangas de tecido de algodão, cuja fabricação aprenderam com os brancos" (CASTELNAU, 1949, p. 243). Além de artefatos usados na guerra, viu nas suas palhoças "grandes balaios de vime e cabaças", mas também não fez qualquer alusão a peças cerâmicas (p. 244). Sobre a pintura, observou que

Os Cadiueus pintam o corpo com jenipapo, desenhando nele figuras muito regulares, feitas de linhas concêntricas e de bonitos arabescos. [...] A mulher do principal da tribo [...] tinha o rosto enfeitado de figuras regulares [...]; o corpo era todo malhado como o da pantera [...]. A maioria das mulheres ostentava no peito um desenho muito curioso, que também era visto, [...], nas ancas dos cavalos e nos lados dos corpos dos cachorros. Soubemos depois que se tratava da insígnia do chefe da família, o qual a imprime em tudo quanto Ihe pertença. (CASTELNAU, 1949, v. 2, p. 244-5).

Sobre essas insígnias, diversos viajantes e estudiosos a elas se referiram, inclusive os tomados como referências neste trabalho. É impróprio supor, a 
exemplo do que afirmou Castelnau, que se tratavam de marcas de propriedade. Os grafismos inscritos nos objetos, nas pessoas e nos animais identificavam as famílias às quais estavam ligados. Darcy Ribeiro (1980) foi enfático ao atestar esse fato.

No início da década de 1860, antes da Guerra da Tríplice Aliança, um viajante italiano transitou pelo território dos Kadiwéu. Bartolomé Bossi era seu nome. Fora marinheiro e, à época, estava fixado em Buenos Aires como fotógrafo. Nas ilustrações do livro que reuniu suas observações de viagem encontra-se o desenho de um índio Kadiwéu tatuado. Sem fazer referência à cerâmica da etnia, o texto colocou em primeiro plano a pintura corporal. Homens e mulheres "Se pintan la cara y el cuerpo con Urucú y Yenipapo introduciendo la pintura en la epidermis; los dibujos no carecen de fantástica simetría. - Las mujeres ponen mayor esmero en este indeleble adorno" (BOSSI, 1863, p. 30). 
Figura 2 - Índio Kadiwéu com pintura corporal

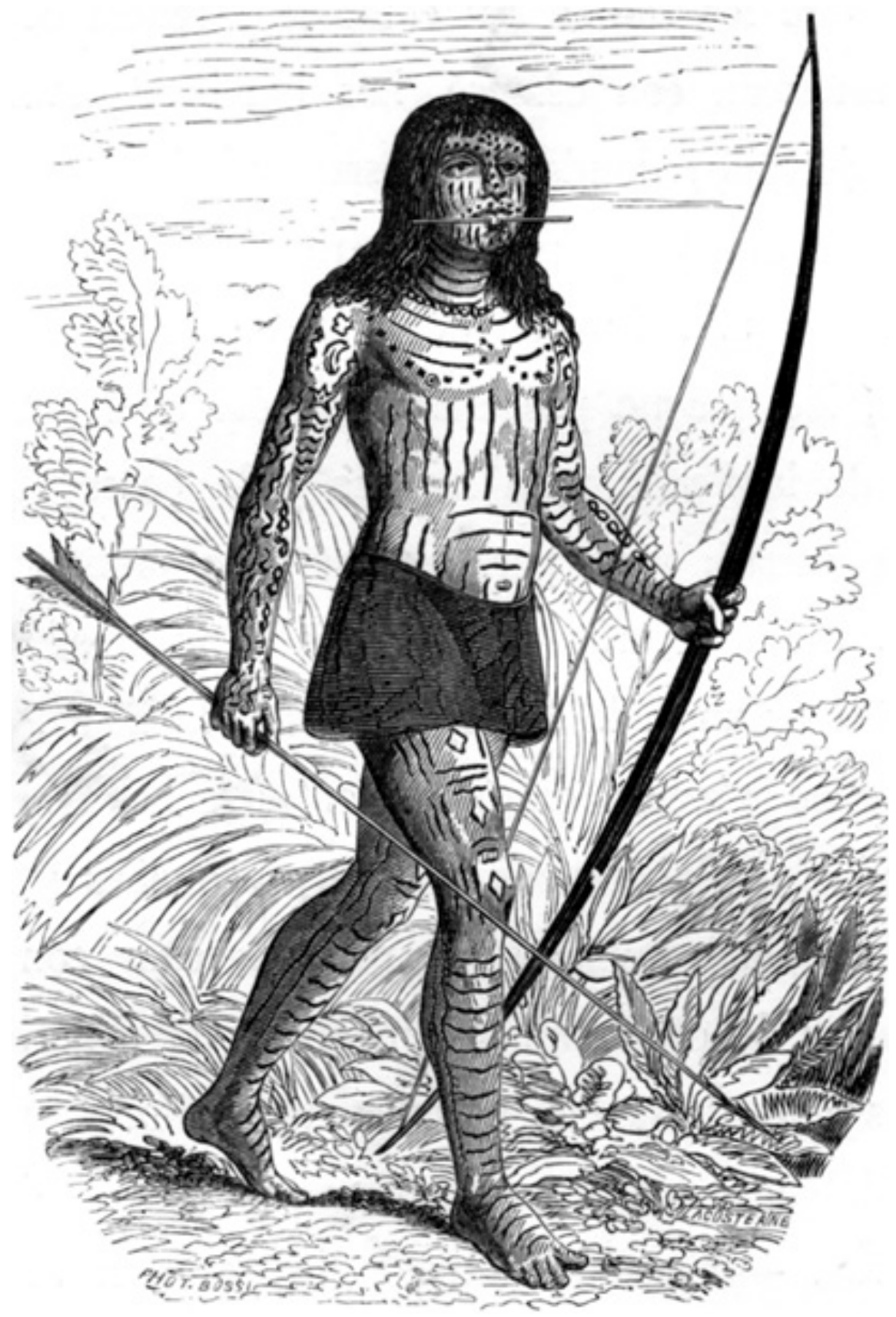

Gravura de Lacoste Ainé baseada em fotografia de Bartolomé Bossi.

Fonte: Bossi, 1863. 
Todos os depoimentos entre o final do século XVIII até a década de 1860, portanto, reiteram a pintura corporal como a atividade artística predominante entre os Kadiwéu. Os registros sobre a cerâmica Guaná e a Kadiwéu são lacônicos. Acentue-se que, nesse interregno, nenhuma informação se referiu à beleza formal dos produtos da arte oleira ou à transposição dos motivos étnicos da pintura corporal para o suporte cerâmico.

\section{OS REGISTROS SOBRE A CERÂMICA KADIWÉU A PARTIR DA DÉCADA DE 1880}

Na década de 1880, transeuntes começaram a ver e descrever peças cerâmicas Kadiwéu que irradiavam beleza pictórica. O primeiro registro detalhado de seu processo de produção foi elaborado por uma naturalista norte-americano, Herbert H. Smith. Quando de sua visita aos Kadiwéu, constituiu uma coleção envolvendo quase duas centenas de peças cerâmicas que enviou ao Museu Nacional, no Rio de Janeiro. Em 1886 publicou O fabrico de louça entre os cadiueus, também reproduzido como apêndice na segunda edição de seu livro Do Rio de Janeiro a Cuyabá: notas de um naturalista (SMITH, 1922).

Smith (1922) viu as ceramistas produzindo e descreveu as etapas do processo de produção das peças, as matérias primas e as técnicas utilizadas pelas artesãs, bem como os instrumentos empregados.

Começou por afirmar que as peças cerâmicas dessa etnia revelavam "gosto artístico refinado", mas não "progresso apreciável" na atividade oleira. Reconheceu que a pintura corporal antecedera à pintura cerâmica e que os "desenhos mais toscos" da primeira mais tarde passaram a ser reproduzidos nos utensílios de argila. Os desenhos da pintura corporal continuavam "mais delicados e complicados que os da louça" e, quanto à execução, era "imensamente superior" (SMITH, 1922, p. 306).

Predominavam, de forma quase absoluta, peças cerâmicas de natureza utilitária. Eram, sobretudo, "panellas, jarras, alguidares e pratos de varias fórmas". As artesãs se "esmeravam" na ornamentação formal. As jarras maiores eram arredondadas, as menores "cylindricas e de pescoço curto". Os pratos e os alguidares tinham formas variadas, desde os "redondos", os "quadrados com ângulos arredondados", os "oblongos" até os "ovaes com azas nos extremos". O fundo era "regularmente encurvado" (SMITH, 1922, p. 306). 
Sobre o "processo de manufactura", Smith (1922) informou que a argila usada como base da cerâmica, o "barro pardo-escuro", era buscada pelos homens nas "baixadas do rio Paraguay". Acentue-se que os Kadiwéu ainda viviam na planície pantaneira e na nesga do Chaco a sudoeste de Mato Grosso. Mas longas eram as "estiradas" para obter a argila, trazida às aldeias em canoas. Então começava a faina das oleiras, exclusivamente mulheres "velhas". As moças só se ocupavam com os "namorados" e o fabrico de "collares de contas com que se adornam" (SMITH, 1922, p. 306-7).

Coberta com "panno velho", a argila ficava repousando sobre um "couro" enquanto a artesã triturava "cacos de louça velha" (SMITH, 1922, p. 306-7). Para tanto, usava "uma pedra lisa e ligeiramente escavada, tendo uma pedra oblonga por mão de pilão" (SMITH, 1922, p. 308). Obtida a quantidade suficiente de "pó", era misturada ao "barro molhado". O material resultante, a "pasta" (RIBEIRO, 1988), era "esfregado e amassado" no couro. Água ia sendo adicionada gradativamente. O "pó", no caso, funcionava como antiplástico, material desengordurante que endurece a argila impedindo que a peça se deforme antes da queima (RIBEIRO, 1988, p. 30).

Atingida a maleabilidade desejada, a artesã juntava um "bolão de barro". Esfregando-o entre as mãos, começava a produzir uma "espécie de corda" de aproximadamente "meio metro" e "uma polegada de grossura". Dispondo-a "em espiral", os "círculos" resultantes iam sendo pressionados com os dedos uns contra os outros. Para produzir uma superfície "macia", o material era "raspado com uma concha de agua doce (Anodonta)". Estava concluído o "fundo de panela ou de prato" (SMITH, 1922, p. 308). Para a elaboração das paredes de uma peça, como a panela por exemplo, o procedimento era análogo, com a diferença de que os roletes iam se superpondo em círculo verticalmente. O último "esbeiça sobre o exterior do que Ihe fica embaixo" e ambos eram presos pela artesã por meio de pressão exercida com os dedos. A intervalos de tempo mais ou menos regulares, com a mesma concha a superfície era alisada. A "beira", quando a peça atingia a altura desejada, era "adelgaçada para fora". Para adornar a "boca", os dedos da artesã também podiam ser usados para imprimir ondulações (SMITH, 1922, p. 308-9). Essa técnica, muito difundida entre diversas etnias indígenas no Brasil para a produção de artefatos cerâmicos, foi denominada acordelado (RIBEIRO, 1988, p. 32). 
Em seguida, as peças eram postas para secar por "vinte e quatro horas" à sombra, durante o dia, ou "encima do rancho, à noite". De novo cada peça era alisada com a concha, "por dentro e por fora" (SMITH, 1922, p. 309).

Seguia-se a etapa de ornamentação. Segundo Smith (1922), nesse "lavor adicional é que as artistas índias acham seu maior enlevo". Inicialmente, ainda "molhadas", as peças passavam por uma operação na qual a ceramista fazia uso de um cordão de fibras de caraguatá (Bromelia plumieri). Esse cordão, pressionado pelos dedos sobre as paredes externas, imprimia sulcos na argila. Operações repetidas, sem "desenho prévio" ou "modelo", conferiam contornos a formas geometrizantes. Retas, curvas ou formas angulares compunham "uma cinta mais ou menos complicada, com um desenho symetrico no meio, quando nos pratos". A impressão por cordão não era aplicada no interior das peças (SMITH, 1922, p. 309).

Prosseguindo a ornamentação, a artesã tomava um pedaço de "oxido de ferro" ou hematita, material acessível nas aldeias, e o ralava "numa pedra com alguma agua" (SMITH, 1922, p. 310). Obtido um líquido avermelhado, a ceramista nele embebia seu dedo indicador e aplicava a tinta num campo da peça demarcado pelas incisões com cordão de caraguatá. No interior das peças, sem as incisões para guiá-las, as artesãs desenhavam livremente.

Era chegada a hora da queima. "Fora do rancho", numa fogueira a céu aberto, "achas de lenha secca" eram colocadas "em cima de um fogo meio apagado". As peças cerâmicas eram depositadas "por cima da superfície" e "uma espécie de gaiola" com outras achas as cobriam. Abanando as brasas, a artesã fazia emergir as labaredas que asseguravam "igual calor a todos os lados da louça" (SMITH, 1922, p. 310).

Após a queima, as peças eram retiradas do fogo "com uns páus" e dispostas no chão. Com "resina preta" extraída do "páu-santo" (Kielmeyera coriácea), a artesã pintava, a quente, os campos não preenchidos pelo engobo de hematita. Smith considerou agradável o resultado estético do contraste entre o preto brilhante do pau-santo e o vermelho do óxido de ferro (SMITH, 1922, p. 310).

A conclusão do processo se dava quando as peças já estavam frias. Água era adicionada a "barro calcareo branco, ou cal obtida de caieira". Com essa solução, também denominada caulim (RIBEIRO, 1988, p. 31), as partes externas eram banhadas. Após a secagem, com "panno velho ou com as mãos", as peças 
eram esfregadas. Essa operação retirava o caulim da superfície externa, à exceção do que ficara impregnado nas "linhas de corda, que assim tornam-se belamente brancas" (SMITH, 1922, p. 310-1).

Portanto, quatro cores eram aplicadas na pintura dos artefatos cerâmicos: a "amarella" da argila, a vermelha da hematita, a preta da resina de pau-santo e a branca do caulim. Segundo Smith, havia peças em que não se aplicava a resina preta e o resultado era uma "combinação muito agradável" das outras três cores. O fundo de algumas, como os pratos, era revestido tão somente de hematita. Sem qualquer outro ornamento, tornava-se "simplesmente vermelho" (SMITH, 1922, p. 311).

Eram os pratos que revelavam "lavor mais artistico". Como "remate final", algumas vezes eram utilizadas "por fóra da beira uma fieira de contas brancas e azues". Pequenos buracos eram abertos nas peças, antes da queima, por onde passavam os fios que sustentavam as contas (SMITH, 1922, p. 311).

Todas as velhas eram ceramistas, mas o grau de perfeição de seus produtos era muito variável. As peças que Smith recolheu para sua coleção foram produzidas por "duas ou três mulheres", as mais hábeis e cuidadosas. O processo de ornamentação ocasionava o maior enlevo nas artesãs. Contudo, depois de concluídos, os artefatos não mais Ihe importavam e eram comercializados "por contas, tesouras, roupas, etc.". Em Corumbá as "melhores peças" eram vendidas por 400 ou 500 réis, mas nas aldeias "obtêem-se muito mais barato" (SMITH, 1922, p. 311-2). Esse registro é relevante, pois atesta que já ocorriam, na penúltima década do século XIX, trocas regulares de peças cerâmicas Kadiwéu no maior centro comercial de Mato Grosso.

As observações finais de Smith foram elogiosas em relação à cerâmica Kadiwéu. Falou da originalidade dos "ornamentos de corda", que ele não viu em outras etnias oleiras, e se impressionou com a beleza dos desenhos, "talvez superior á de qualquer tribu de indios existentes na America" (SMITH, 1922, p. 312).

Na década seguinte, o artista plástico italiano, Guido Boggiani, esteve por duas vezes entre os Kadiwéu. Na primeira visita, em 1892, fez inúmeros desenhos em aquarela. Na segunda, em 1897, já dispunha de uma máquina fotográfica e, com ela, captou imagens das etnias que, desde o Paraguai, viviam às margens 
do rio homônimo. Deixou para a posteridade importantes coleções de objetos etnográficos obtidos na região, atualmente disponíveis em museus de Roma, Berlim e Stuttgard.

Evitando as repetições desnecessárias, acentue-se que Boggiani também não economizou elogios em relação à pintura corporal Kadiwéu. Chamou sua atenção uma cativa chamacoco que pintava "a cara em faixas vermelhas" e tinha "o peito e os braços recobertos de belos desenhos em negro" (BOGGIANI, 1945, p. 118). O vermelho derivava do urucu e o negro do jenipapo. O artista descreveu detalhadamente a produção da pasta de urucu (BOGGIANI, 1945, p. 140).

Viu as artesãs praticando a técnica do acordelado e fez registros de todas as etapas do processo. Escreveu sobre os recursos empregados para a conformação das peças cerâmicas, desde as matérias primas consumidas até os instrumentos de trabalho utilizados. A sua descrição guarda inteira compatibilidade com o que observou Smith na década anterior. A única diferença, pouco relevante, mas digna de ser apontada, se refere ao uso de "pós de côcos torrados" como antiplástico, ao invés de cacos cerâmicos moídos (BOGGIANI, 1945, p. 141).

Quanto à "ornamentação, pintura e cozimento" das "louças", discorreu, inicialmente, sobre a operação por meio da qual as artesãs realizavam incisões com cordão de caraguatá nas peças ainda não queimadas. Elas conferiam à superfície "linhas direitas, curvas ou quebradas, ou paralelas ou cruzadas". Seguia-se a secagem e, depois, a pintura com engobo de hematita sobre alguns campos demarcados pelas incisões. A queima, operação consecutiva, se concluía quando o consumo total da lenha se completava. A argila, antes "acinzentada", após a queima ganhava a cor "amarelo avermelhada". A peça "ainda quente" passava pela operação de pintura com resina de pau-santo, quando eram recobertos alguns campos onde não se aplicara a hematita. Nesses locais a pintura ganhava "um verniz negro esverdeado" (BOGGIANI, 1945, p. 160).

Uma impropriedade se instaura no texto de Boggiani quando, em outro passo, afirma ser a cor negra das peças cerâmicas decorrentes do uso de solução de "pó de carvão e água misturados ao suco de jenipapo" (BOGGIANI, 1945, p. 161). Ora, ele próprio descreveu, no caso da cerâmica, que essa cor era obtida por meio da resina de pau-santo. A combinação do jenipapo e do carvão se aplicava basicamente à pintura corporal e em couro de animais. 
Também o uso de caulim nos sulcos impressos pelo cordão de caraguatá ganhou uma descrição distinta da realizada por Smith. A frio, com um "palito" (BOGGIANI, 1945, p. 161), somente os sulcos eram preenchidos com o engobo de argila branca diluída em água. Diferente do que observou o naturalista norte-americano, as peças já não recebiam um banho dessa solução, para, em seguida, por fricção com pano velho, sofrer limpeza nos campos previamente pintados.

Embora tenham sido constatadas pequenas variações em aspectos específicos da produção de peças cerâmicas, as cores continuavam as mesmas quatro descritas por Smith.

Quanto à pintura das peças cerâmicas, relevante é o fato de que a colocou no mesmo patamar da pintura corporal. Salientou que os desenhos, nos dois casos, "são cheios de gôsto e de caráter." (BOGGIANI, 1945, p. 118). É possível inferir que a ornamentação das peças cerâmicas passara por um processo de aperfeiçoamento no interregno de uma década, pois Smith afirmara que a execução da pintura corporal era "imensamente superior".

Ao concluir suas observações, Boggiani fez distinção entre as peças cerâmicas utilitárias e as ornamentais. Acentuou que somente as últimas eram produzidas com todos os requintes do processo descrito. As utilitárias "quase nunca são ornadas" e "resistem perfeitamente ao fogo para nelas se cozinhar as comidas" (BOGGIANI, 1945, p. 161).

Quando Lévi-Strauss visitou os Kadiwéu, em meados da década de 1930, discorreu longamente sobre a pintura e pouco sobre a cerâmica. Constatou que a "prosperidade" era coisa do passado nas suas aldeias (LEVI-STRAUSS, 1945, p. 181). À pobreza material vivida pela etnia correspondia o estado de "completa degenerescência" de seu artesanato cerâmico, mesmo sendo uma de suas atividades principais (LEVI-STRAUSS, 1945, p. 194). Sua ressalva em relação à pintura corporal foi expressiva, mesmo reconhecendo que somente algumas artesãs muito velhas mantinham a habilidade antiga. Reuniu " 400 " desenhos e, depois de ter visto a coleção constituída por Darcy Ribeiro "15 anos mais tarde", patenteou a conservação dos seus motivos formais no tempo e a mesma "execução segura" (LEVI-STRAUSS, 1945, p. 193-4). Segundo ele, os grafismos que ornavam as peças cerâmicas eram "relativamente simples". Envolviam "espirais, esses, cruzes, maclas, gregas e volutas", mas ganhavam sempre combinações originais e refinadas 
(LEVI-STRAUSS, 1945, p. 195-8). Sobre o significado dessa "estilística indígena", pesaroso reconheceu ser desconhecido, pois os informantes da etnia "invocam a ignorância ou o esquecimento para tudo o que se refere às decorações mais complexas" (LEVI-STRAUSS, 1945, p. 195).

Se, no passado, a ornamentação do corpo era objeto de tatuagem ou de pintura, observou que só a segunda prática se mantinha. Às mulheres cabiam, exclusivamente, todas as modalidades de pintura. "Algumas" eram "peritas incontestáveis" (LEVI-STRAUSS, 1945, p. 191). O refinamento dos desenhos aplicados ao corpo fez Lévi-Strauss tratar a operação como "cirurgia pictórica" que, ao cabo, realizava "uma espécie de enxerto de arte no corpo humano" (LEVI-STRAUSS, 1945, p. 197).

Na atividade cerâmica as mulheres realizavam "uma arte não-representativa". Dois estilos estavam envolvidos: "um angular e geométrico, o outro curvilíneo e livre" (LEVI-STRAUSS, 1945, p. 199). No caso das peças cerâmicas os dois estilos se alternavam entre "as bordas ou o enquadramento" ou, ainda, entre o "pescoço dos vasos" e o "bojo" (LEVI-STRAUSS, 1945, p. 199). A decoração respeitava, também, o "duplo princípio de simetria e de assimetria simultâneamente aplicados" (LEVI-STRAUSS, 1945, p. 200).

Quando de sua visita às aldeias Kadiwéu, Lévi-Strauss fixou como base operacional a Fazenda Francesa, próxima do território indígena. Nessa época, os índios ainda viviam "nas terras baixas da margem esquerda do Rio Paraguai". A propriedade onde se instalaram os membros da expedição era administrada por dois franceses que revelavam pouco apreço pelos indígenas. Viam-nos como "preguiçosos e degenerados, ladrões e bêbados", daí serem "rudemente expulsos das pastagens quando nelas tentavam penetrar". Ambos tentaram dissuadir Lévi-Strauss de sua empreitada. Segundo depoimento do antropólogo francês, todos ficaram muito surpresos quando do retorno de sua expedição, após a visita aos Kadiwéu. Traziam "os bois tão carregados quanto os de uma caravana”. Entre os produtos adquiridos encontravam-se "grandes jarras de cerâmica pintada e gravada, couros de cabritos iluminados de arabescos" e outras peças artesanais (LEVI-STRAUSS, 1945, p. 175).

Ainda segundo o depoimento do antropólogo, esse episódio gerou mudança de atitude nos administradores e trabalhadores da fazenda francesa. Desde então, os índios passaram a ser bem recebidos nos seus domínios, onde come- 
çaram a trocar regularmente os seus produtos. A sede da propriedade passou a ser decorada com "peles pintadas" e "cerâmicas indígenas por todos os cantos" (LEVI-STRAUSS, 1945, p. 175).

Estudos mais sistemáticos e extensos sobre a arte Kadiwéu foram desenvolvidos pelo antropólogo Darcy Ribeiro. Na década de 1940 conviveu com os membros da etnia e analisou seus costumes. Acentuou que esse momento estava profundamente marcado pelo processo de "destribalização" dos Kadiwéu em face da sociedade capitalista envolvente. Como tantos outros, se encantou com as diferentes modalidades de pintura das artistas Kadiwéu, inclusive sobre o suporte cerâmico. Ao comparar a coleção que constituiu com as peças reunidas por Boggiani no final do século XIX, reconheceu que pouco se perdera "quanto à forma, mas a execução dos desenhos decaiu muito". Para ele, já não existia "aquela elaboração perfeita que indica um cultivo muito mais intenso desta arte" (RIBEIRO, 1980, p. 292). A "riqueza de cores" e o "virtuosismo de execução" teriam se perdido no passado (RIBEIRO, 1980, p. 278).

Listou quatro razões para explicar a decadência. A primeira residiria na intensificação do comércio, pois "o mercado não exige qualidade especial". O aumento da demanda fez com que a produção se tornasse mais apressada. A segunda seria devida à mudança do habitat, desde que os Kadiwéu se deslocaram do Chaco e dos "campos do Pantanal, para a zona de matas ao pé da Serra da Bodoquena". A carência de algumas matérias primas teria interferido negativamente, em especial na ornamentação. A terceira se devia à maior convivência com o homem branco, especialmente lesiva quando os indígenas incorporaram os "estigmas de inferioridade" em relação ao que produziam e substituíram, por exemplo, suas peças cerâmicas pela "lataria" comprada no mercado (RIBEIRO, 1980, p. 259). A quarta razão da decadência do desenho seria explicada pelo abandono da prática do "cativeiro" exercida no passado sobre outras etnias. As mulheres tiveram que substituir os cativos no exercício de tarefas árduas e pesadas do cotidiano. Antes, elas dispunham de tempo livre para se dedicar ao fazer artístico. Isso explicaria sua devoção à arte oleira no passado, sua identificação subjetiva com os produtos do trabalho, seu envolvimento com o cuidado técnico e o prazer estético que experimentavam. Essa "vontade de beleza" (RIBEIRO, 1980, p. 257), como acentuou o antropólogo, explicava, em grande parte, a emergência e a consolidação das artes ligadas ao desenho entre as mulheres Kadiwéu em tempos pregressos (RIBEIRO, 1980, p. 262). 
Para Ribeiro, a pintura, "na fase de destribalização" vivida pelos Kadiwéu, representava "o maior motivo de orgulho tribal" (RIBEIRO, 1980, p. 269). Ele encontrou artistas mais velhas que despontavam pela habilidade. Falou de Anoã, uma das principais. Foi ela quem produziu grande parte dos desenhos coletados pelo antropólogo, "tanto os executados em cadernos como sobre couros e outros artefatos” (RIBEIRO, 1980, p. 270).

Reforçou informações dos viajantes que lhe antecederam. Reconheceu, por exemplo, que as artistas não observavam esboços prévios ao pintarem. Simplesmente reproduziam formas de inspiração geométrica que estavam guardadas na memória (RIBEIRO, 1980, p. 270). Realizavam "combinações de pontos, elementos retos e curvos, formando todas as figuras geométricas abstratas, nas mais variadas composições". O "ritmo" dava "dinamismo a esta arte indiferente à vida e ao movimento" (RIBEIRO, 1980, p. 271). Essa predileção pelos motivos geométricos abstratos opunha a arte das mulheres à dos homens. Na madeira, por exemplo, estes reproduziam motivos figurativos zoomorfos ou antropomorfos que remetiam ao cotidiano e ao ambiente em que viviam.

Sobre as cores usadas na pintura corporal foi categórico ao reduzi-las a três: "o negro azulado do suco de jenipapo", "as meias-tintas de fundo com o vermeIho do urucu" e as "manchas brancas feitas com polvilho de cerne da palmeira bocaiúva” (Acrocomia mokayayba) (RIBEIRO, 1980, p. 278-81).

Ao discorrer especificamente sobre a cerâmica, reforçou as descrições anteriores de Smith, Boggiani e Lévi-Strauss. Fez o registro detalhado da técnica do acordelado, do processo de ornamentação (RIBEIRO, 1980, p. 288) e da queima das peças. Afirmou que os grafismos aplicados aos artefatos cerâmicos eram reproduções daqueles usados na pintura corporal. Tratava-se de transposição, portanto, pois a cerâmica correspondia a manifestação artística mais recente (RIBEIRO, 1980, p. 290).

Em relação às cores usadas na ornamentação das peças cerâmicas, listou cinco: o "verniz negro do pau-santo", "o amarelo vítreo do angico" (Piptadenia sp), o branco decorrente de "solução leitosa de água e cal, cinza branca ou tabatinga", "o amarelo avermelhado em tom de tijolo queimado", que emergia das partes não pintadas, e o vermelho da hematita (RIBEIRO, 1980, p. 290-1). Algumas peças revelavam refinamento no uso de todas essas cores. Outras faziam belas 
combinações, mesmo quando nem todas eram utilizadas. Sobre as missangas, apesar da ainda viva atração que exerciam sobre as artesãs, afirmou que havia rareado seu uso nas peças cerâmicas.

Na modelagem das peças as artesãs Kadiwéu revelavam capricho exemplar. Os "resultados notáveis" se encarnavam nas "terrinas em quadrados, com ângulos arredondados", nas "moringas ornitomorfas" e nas "tijelas de curiosos trejeitos". Como se percebe, as peças reproduziam suas antigas formas utilitárias. Ribeiro nomeou, ainda, os alguidares, os "potes baixos", os "vasos altos" e as "moringas de duas bocas" (RIBEIRO, 1980, p. 291).

Pesquisas recentes revelam algumas transformações sensíveis no quadro delineado. Inicialmente deve ser acentuado o fator determinante que, desde a década de 1970, intensificou a produção e a comercialização do artesanato indígena em Mato Grosso do Sul. Como se depreende dos relatos de Lévi-Strauss e de Darcy Ribeiro, a cerâmica Kadiwéu estava em decadência no segundo terço do século XX. Contudo, o turismo de pesca, a partir da década de 1970, promoveu o surgimento de empresas devotadas à atividade. Esse desabrochar se fez acompanhar da expansão de infraestrutura, em especial estradas, frotas de barcos adequados à pesca e hotéis. Os turistas afluíram em grande quantidade. Pontos de comercialização de artesanato surgiram nas principais cidades da região. Foram os casos das unidades da Casa do Artesão em Corumbá e Campo Grande na década de 1970. Os postos de gasolina ao longo da BR 262, entre Campo Grande e Corumbá, abriram espaços para a comercialização de artesanato em lojas anexas. O posto Pioneiro, próximo de Miranda, é o melhor exemplo. Nele, divisando com o restaurante, uma ampla loja expõe e comercializa produtos artesanais da região, inclusive artefatos indígenas (ALVES, 2014; 2020).

A expansão do mercado de produtos artesanais, por força da presença de turistas na região, criou as condições objetivas para o incremento do artesanato cerâmico indígena. Mas, ao lado da mudança de habitat, a expansão do mercado gerou estímulos que interferiram na produção das diversas etnias oleiras em Mato Grosso do Sul. O quadro das transformações operadas na cerâmica Kadiwéu é sumariado na sequência.

Os efeitos da mudança de habitat se mostraram, nitidamente, na ornamentação dos artefatos cerâmicos Kadiwéu. Como as matérias primas empregadas 
sempre foram aquelas disponíveis no ambiente circundante, o deslocamento da etnia da planície pantaneira impôs ajustamentos. Um deles foi o abandono do uso da hematita e do angico. Em compensação, a partir da fixação das aldeias na Serra da Bodoquena se colocou à disposição das oleiras uma quantidade apreciável de argilas coloridas.

Antes, as cores mantiveram-se quase invariáveis, o que se revelou de forma consistente desde os registros de Herbert Smith até os de Darcy Ribeiro, passando pelos de Guido Boggiani e de Lévi-Strauss. Resumiam-se ao tom amarelo da argila, ao vermelho da hematita, ao preto da resina de pau-santo e ao branco do caulim. Uma variação foi destacada por Lévi-Strauss e Ribeiro, ao indicarem que as artesãs obtinham uma quinta cor: o "amarelo vítreo" derivado do angico.

Na Serra Bodoquena, a grande variedade de argilas coloridas viabilizou a produção de artefatos cerâmicos multicoloridos (SÁ; INAGAKI, 2014; ALVES, 2017). Engobos de cores variadas passaram a ser utilizados sistematicamente pelas artesãs. 
Figura 3 - Pote cerâmico contemporâneo produzido com aplicação de engobos de cores variadas

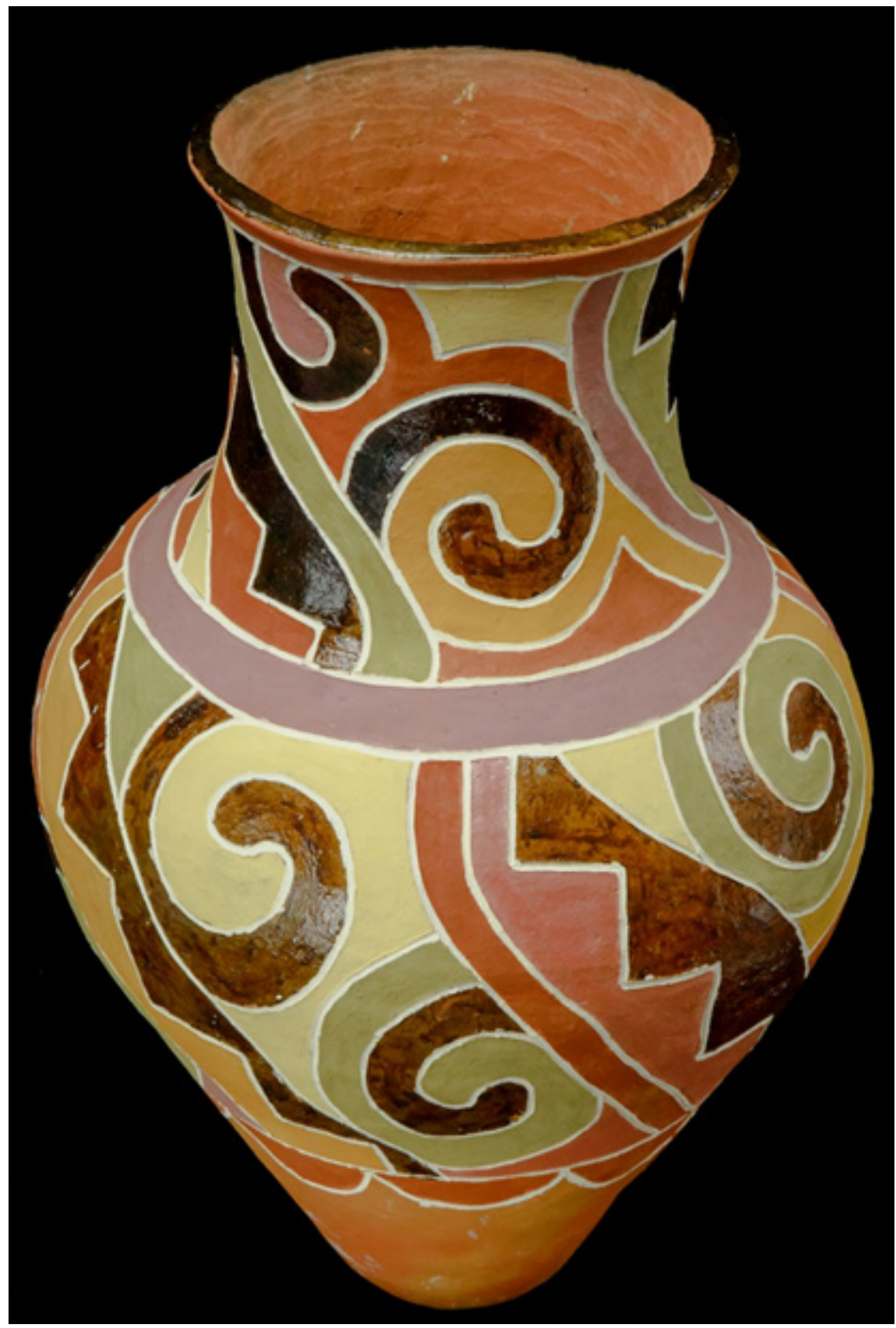

Fonte: Acervo do Instituto Cultural Gilberto Luiz Alves, 2019. 
Quanto às transformações imanentes ao mercado, como já afirmara Darcy Ribeiro, foi aligeirado o processo de produção. Em decorrência, comprometeu-se a resistência dos produtos e a fixação da pintura. As peças são quebradiças e pouco afeitas à manipulação nos postos de comercialização e no transporte. A queima, realizada precariamente em fogueiras a céu aberto, atinge temperatura de, no máximo, 500 graus centígrados (ALVES, 2014). Uma agravante se sobrepõe, ainda, pois o próprio vento contribui para consumir rapidamente as madeiras usadas na queima.

Figura 4 - Fragmentos de peça cerâmica produzida em 2014. A coloração escura nas partes internas é indicativa de queima insuficiente e pouca resistência.

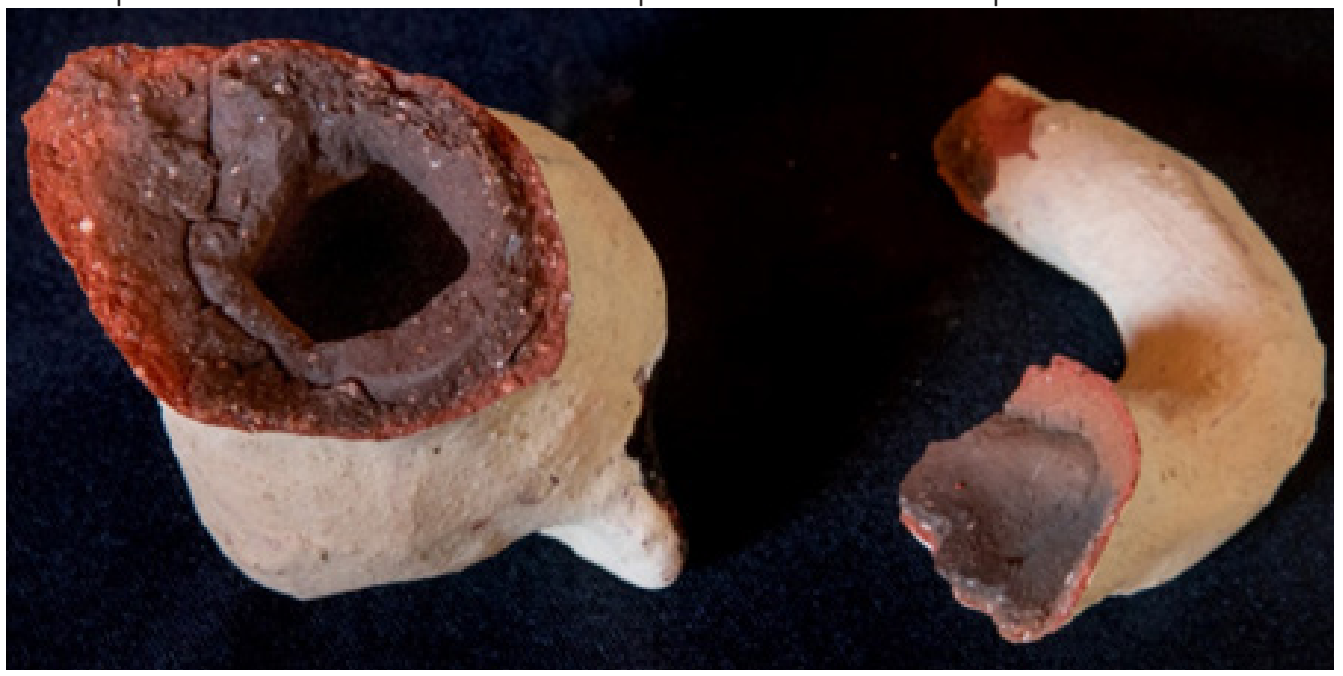

Fonte: Acervo do Instituto Cultural Gilberto Luiz Alves, 2019.

Ao contrário do que ocorria no passado, a pintura com os engobos de argilas coloridas já não se dá antes da queima dos artefatos. É realizada à frio na superfície das peças, depois dessa operação. Em decorrência, os engobos se fixam precariamente perdendo por atrito, em seguida, as cores originais. O simples borrifo de água nas áreas pintadas ocasiona danos. O mesmo não ocorre nas áreas recobertas com resina de pau-santo, pois aplicada a quente. 
Figura 5 - Placa cerâmica representando um peixe, produzida em 2014 (imagem superior). Três anos depois, a pintura com engobos de argilas coloridas já apresentava sensível despigmentação (imagem inferior)

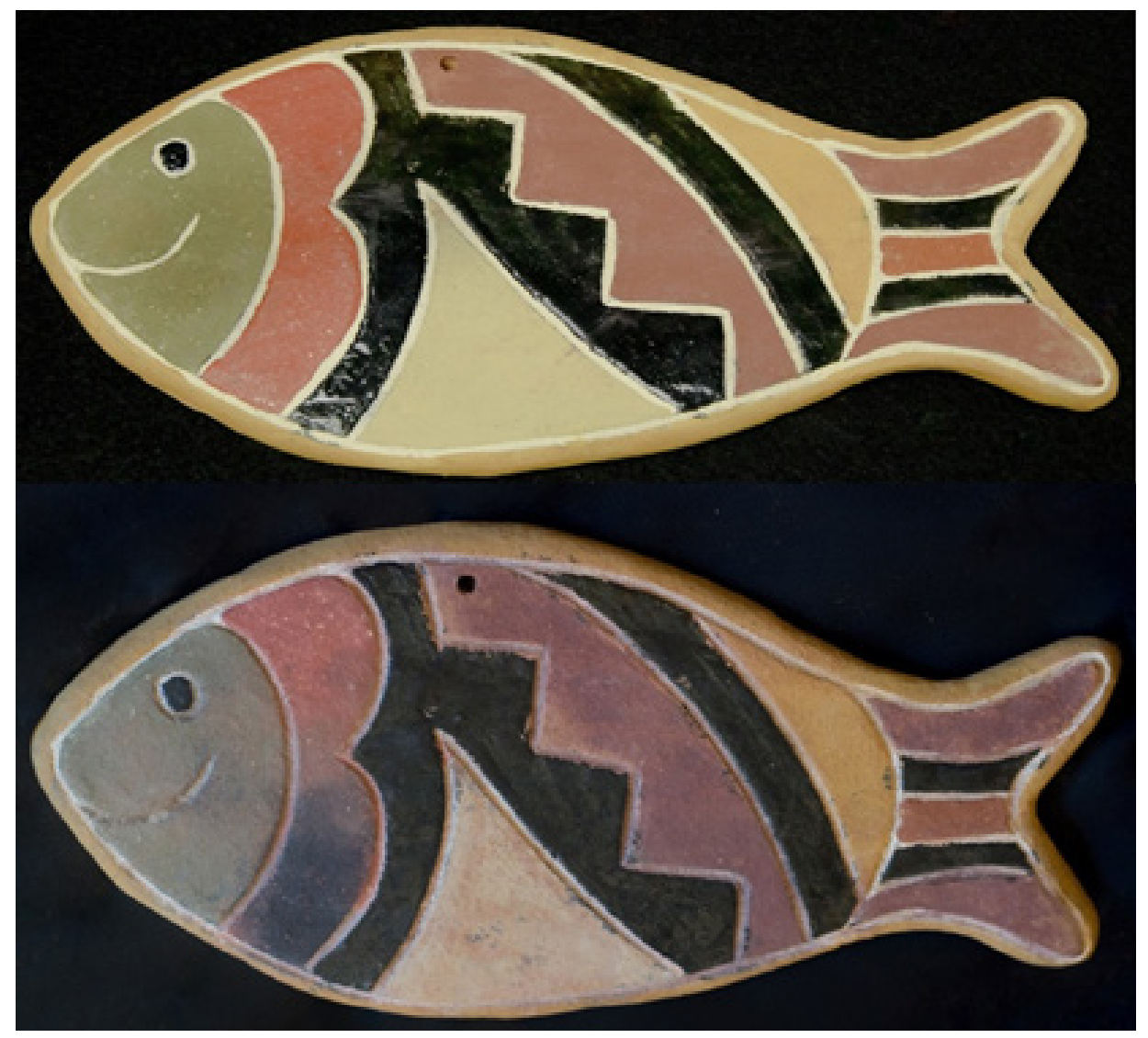

Fonte: Acervo do Instituto Cultural Gilberto Luiz Alves, 2019.

Por força da expansão do mercado, também ocorreram acentuadas mudanças na forma e nas dimensões dos artefatos cerâmicos. No passado eram produzidas exclusivamente peças utilitárias. Alguns adornos ornitomorfos, às vezes, eram modelados nas tampas de moringas ou nas extremidades de panelas e de travessas. Atualmente se difundiu a tendência de miniaturização dessas peças. Assim, elas passaram a atender confortavelmente às demandas dos turistas, pois se ajustam melhor aos reduzidos espaços de suas bagagens. Ainda quanto à forma, também miniaturizadas, passaram a ser modeladas figuras de animais domésticos ou selvagens que vivem no ambiente circundante. São capivaras, onças, porcos, 
jacarés, tartarugas, cachorros, bois, macacos, cobras, peixes e aves. A diversificação se acentuou quando começaram a ser produzidas, também, peças ornamentais como cinzeiros ou placas passíveis de serem dependuradas em paredes. O último momento desse processo de diversificação formal das peças cerâmicas se configurou na produção de artefatos antropomórficos. Recentemente, começaram a abastecer os postos de comercialização peças cerâmicas que reproduzem homens e mulheres no exercício das atividades cotidianas.

Retornando à lição aristotélica, pode-se concluir que a cerâmica Kadiwéu tornou-se outra coisa em nossos dias. Foi-se o tempo em que as artesãs produziam utensílios, valores de uso consumidos no dia a dia para atender necessidades da vida doméstica. Já não produzem panelas para cozinhar alimentos, potes para armazenar água ou moringas para transportá-la, nem pratos para comer. Desde que o mercado gerou demandas para o artesanato indígena, as peças produzidas passaram a exercer, tão somente, função ornamental. Na sociedade regida pelo mercado, antigos valores de uso das artesãs Kadiwéu ganharam a condição predominante de valores de troca. Tornaram-se mercadorias (MARX, 2013). Agora, as peças adquiridas pelos turistas se realizam como valores de uso embelezando cantos e paredes de suas casas ou de seus móveis. Esse trânsito dos utensílios para mercadorias, entre outras consequências, salvou a própria arte oleira indígena da extinção.

\section{CONSIDERAÇÕES FINAIS}

É evidente o dinamismo da cerâmica indígena. Ela nunca foi nem é estática. Mesmo em face da permanência das técnicas de produção e dos instrumentos de trabalho ancestrais, em especial no que se refere às matérias primas ocorreram ajustamentos às condições ambientais. Com a expansão do mercado, também ocorreu uma diversificação formal das peças cerâmicas e se introduziram algumas práticas que, tendo aligeirado o processo de produção, contribuíram para tornar os artefatos menos resistentes e a sua pintura mais precária.

Cabe considerar, contudo, uma alvissareira tendência de melhoria da cerâmica indígena Kadiwéu. Essa tendência foi posta como possibilidade pela atuação da Associação das Mulheres Artistas Kadiwéu (AMAK). É central em sua direção a preocupação com o aperfeiçoamento dos produtos cerâmicos da etnia. O projeto de pesquisa "Artesanato indígena em Mato Grosso do Sul: mudanças e inovações 
tecnológicas" (ALVES, 2017) teve importante papel nessa iniciativa, pois propiciou contatos das artesãs com especialistas acadêmicos das áreas de física, de química e com artistas plásticos.

Para ilustrar, por solicitação da presidente da AMAK, Creuza Vergílio, foi viabilizada uma oficina na Aldeia Alves de Barros com a artista plástica Angela Miracema Batista Fernandes. O livro de Darcy Ribeiro (1980), Kadiwéu, foi manuseado no início das atividades e algumas partes foram lidas para mais de quarenta artesãs. As informações sobre soluções ornamentais, já em desuso, reavivaram interesses das artesãs. Instaurou-se o desejo de recuperar o uso das contas coloridas e missangas nas peças cerâmicas, bem como o da pintura em couro de animais. Nos ensaios ocorridos, em seguida, mantiveram-se as técnicas ancestrais com algumas adaptações no que se refere às matérias primas. No caso do couro, por exemplo, foram usados retalhos do produto industrializado, baratos e acessíveis. A pintura manteve o emprego do carvão em pó, mas, para favorecer a fixação, misturado a cola branca diluída (FERNANDES, 2020).

Figura 6 - Pintura em couro, experiência realizada pela artesã Creuza Vergílio

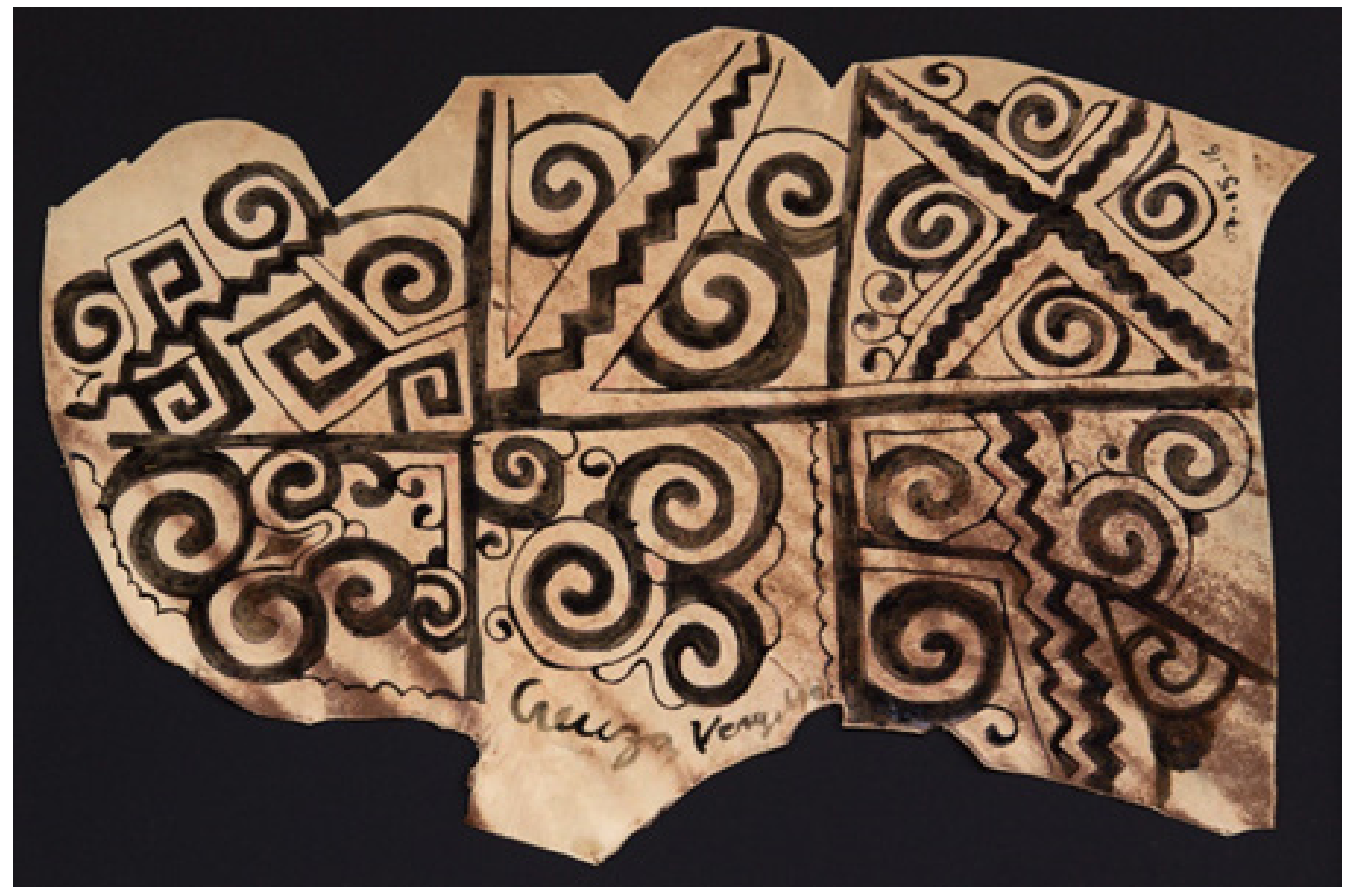

Fonte: Acervo do Instituto Cultural Gilberto Luiz Alves, 2019. 
Uma jovem artista Kadiwéu, Nayo Kolaté, iniciou, também, experiência de pintura em tela. Utilizando pigmentos naturais, ela vem transposto para esse suporte os motivos geometrizantes que tanta admiração exerceram sobre viajantes e antropólogos no passado e ainda exercem sobre os turistas no presente.

Figura 7 - Pintura com pigmentos naturais, realizada em tela por Nayo Kolaté

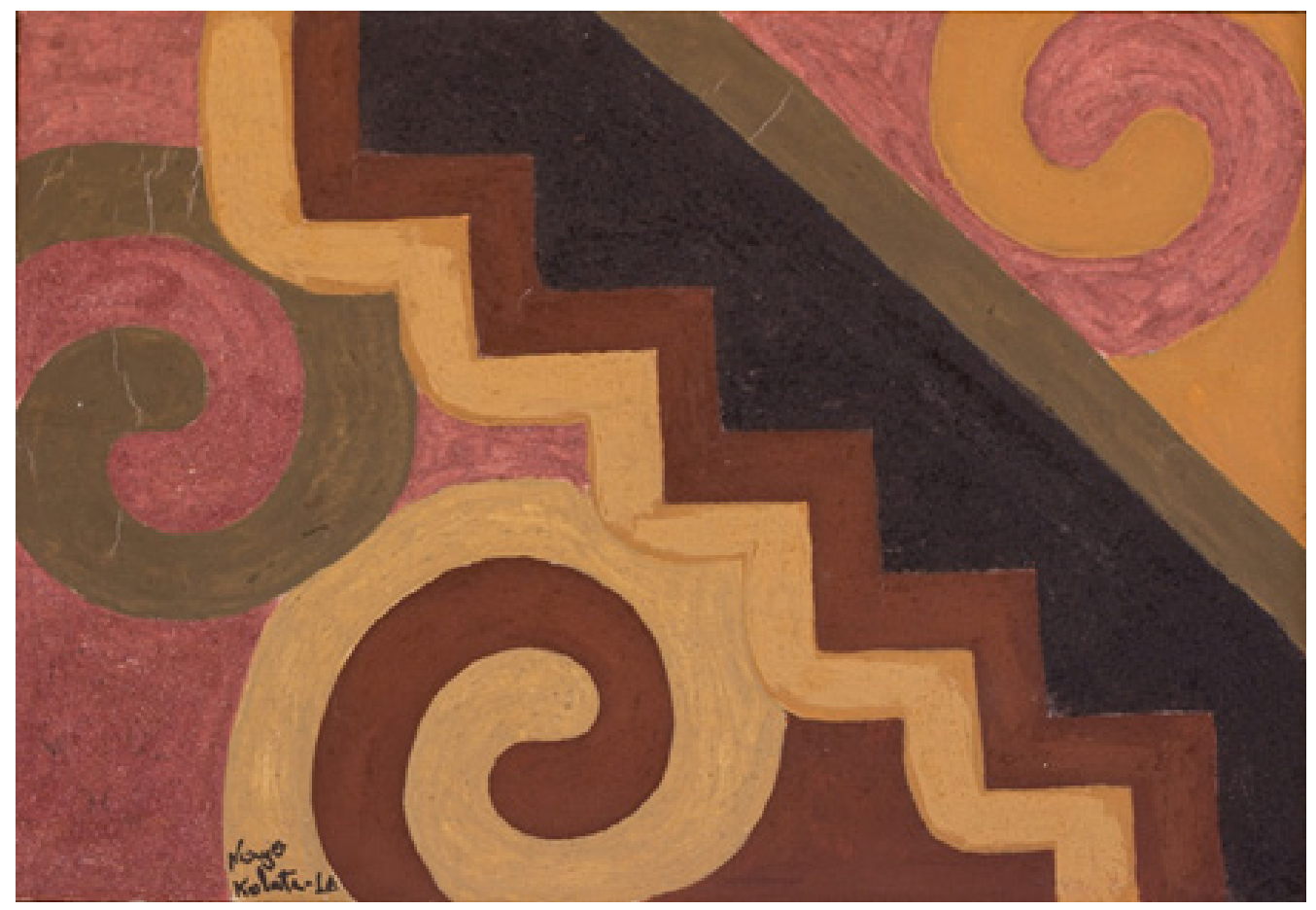

Fonte: Acervo do Instituto Cultural Gilberto Luiz Alves, 2019.

Creuza Vergílio, no final de 2017, produziu ainda um conjunto de peças cerâmicas que evidenciam iniciativas de aperfeiçoamento. A resistência foi sensivelmente melhorada pela realização de experiência de dupla queima. Pela ação do fogo, todos os engobos coloridos, aplicados antes da operação de queima, se fixaram apropriadamente à superfície das peças. Também foi recuperado o uso da hematita para a obtenção da cor vermelha.

As artesãs Kadiwéu querem mais, segundo a presidente da AMAK. Os rumos de suas experiências vão além do processo de dupla queima e da recuperação do uso da hematita na pintura. Verifica-se na Figura 8, também, a aplicação de 
missangas na ornamentação. Mas a própria presidente asseverou que essa iniciativa foi só uma experiência. Visando aperfeiçoar ao máximo seus artefatos, as artesãs pretendem, no lugar das missangas, utilizar sementes dos ricos recursos botânicos disponíveis na Reserva Kadiwéu em Porto Murtinho.

Figura 8 - Alguidar produzido por meio de dupla queima, pintado com hematita e decorado com missangas

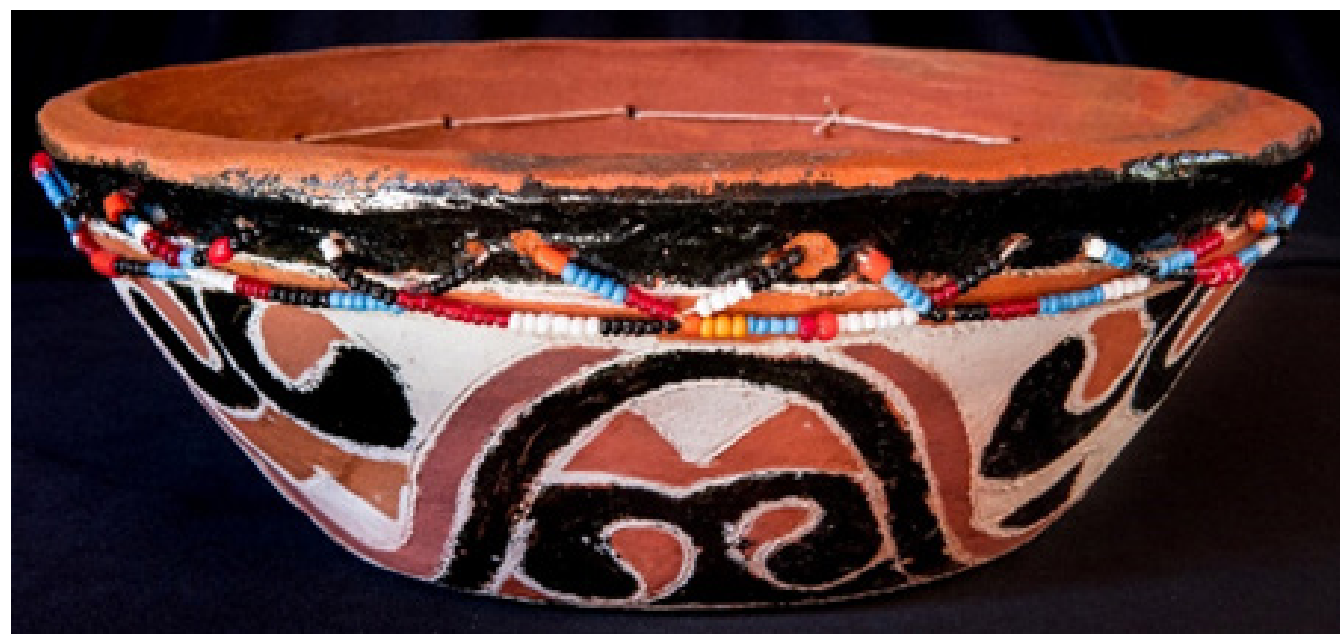

Fonte: Acervo do Instituto Cultural Gilberto Luiz Alves, 2019.

Professores da área de física da Universidade Federal de Mato Grosso do Sul (UFMS) sugeriram a utilização de tijolos refratários para construir uma cerca no entorno das fogueiras rústicas escavadas no chão a céu aberto. Dessa forma, o tempo de queima aumentaria, pois a fogueira estaria protegida contra a ação do vento. Esse artifício também elevaria a temperatura de queima, que, no processo convencional em uso, atinge no máximo quinhentos graus centígrados.

Essas experiências são alvissareiras, repita-se, pois atestam a convergência de condições objetivas e subjetivas favoráveis ao incremento da produção e meIhoria dos artefatos cerâmicos indígenas. A pressão pela expansão do mercado e o desejo das artesãs conjugam-se para a adoção de soluções que elevem a resistência dos produtos, tornando-os mais aptos à manipulação no transporte e nas lojas comerciais, menos sujeitos às perdas, portanto, fixem a pintura de forma a evitar a despigmentação precoce e enriqueçam a ornamentação. 


\section{REFERÊNCIAS}

ALVES, G. L. Utensílio, objeto de arte e mercadoria: a cerâmica indígena em Mato Grosso do Sul. In: ALVES, G. L. (Org.). Temas indígenas sul-mato-grossenses. Curitiba: Appris, 2020. p. 9-35.

ALVES, G. L. Relatório do projeto de pesquisa artesanato indígena, mudanças e inovações tecnológicas em Mato Grosso do Sul. Campo Grande: Uniderp, 2017.

ALVES, G. L. Arte, artesanato e desenvolvimento regional: temas sul-mato-grossenses. Campo Grande: UFMS, 2014.

ARISTÓTELES. Política. Madrid: Gredos, 1988.

BOGGIANI, G. Os caduveo. São Paulo: Martins Fontes, 1945.

BOSSI, Bartolomé. Viagem pintoresco por los rios Paraná, Paraguay, San Lorenzo, Cuyabá y el Arino, tributario del grande Amazonas: con la descripción de la provincia de Mato Grosso bajo sul aspecto físico, geográfico, mineralojico y sus producciones naturales. Paris: Libreria Parisiense, 1863.

CANAZILLES, K. S. A. A produção e a comercialização do artesanato kinikinau em Mato Grosso do Sul. 2013. Dissertação (Mestrado em Meio Ambiente e Desenvolvimento Regional) - Universidade Anhanguera-Uniderp, Campo Grande, MS, 2013.

CASTELNAU, Francis. Expedição às regiões centrais da América do Sul. Tradução de Olivério M. de Oliveira Pinto. São Paulo: Brasiliana, 1949. v. 2.

CHAVES, F. A. A produção da cerâmica terena da aldeia Cachoeirinha em Miranda, MS. 2015. Dissertação (Mestrado em Meio Ambiente e Desenvolvimento Regional) Universidade Anhanguera-Uniderp, Campo Grande, MS, 2015.

FERNANDES, Angela Miracema Batista. Conexão Kadiwéu: depoimento. In: ALVES, Gilberto Luiz (Org.). Temas indígenas sul-mato-grossenses. Curitiba: Appris, 2020. p. 111-4.

FERREIRA, Joaquim Alves. Notícia sobre os índios de Mato Grosso dada em ofício de 2 de Dezembro de 1848 ao Ministro e Secretário de Estado dos Negócios do Império, pelo Diretor Geral dos Índios da então Província. Cuiabá: IHGMT, 2001. (Publicações avulsas, 33).

FERREIRA, Alexandre Rodrigues. Viagem filosófica: pelas capitanias do Grão-Pará, Rio Negro, Mato Grosso e Cuiabá. Memórias antropologia. Rio de Janeiro: Conselho Federal de Cultura/Departamento de Imprensa Nacional, 1974. v. 1. 
FERREIRA, Alexandre Rodrigues. Viagem filosófica: pelas capitanias do Grão-Pará, Rio Negro, Mato Grosso e Cuiabá, 1783-1792. Iconografia. Rio de Janeiro: Conselho Federal de Cultura; Departamento de Imprensa Nacional, 1971. v. 1.

GODOY, A. F. A cerâmica terena e sua produção na arte indígena do Mato Grosso do Sul. 2001. Monografia (Especialização em História Regional) - Universidade Federal de Mato Grosso do Sul, Aquidauana, MS, 2001.

GOMES, L. S. A produção da cerâmica pelas mulheres terena: interfaces entre cultura, material, gênero e território tradicional. In: REUNIÃO BRASILEIRA DE ANTROPOLOGIA [ABA], 26., 1-4 jun. 2008, Porto Seguro, Bahia. Anais [...]. Brasília: ABA. Disponível em: http://www.abant.org.br/conteudo/ANAIS/CD_Virtual_26_RBA/grupos_de_trabalho/ trabalhos/GT\%2014/luciana\%20scanoni\%20gomes.pdf. Acesso em: 1o out. 2018.

GRAZIATO, V. P. P. O universo feminino na cerâmica kadiwéu. In: SILVA, J (Org.). Kadiwéu: senhoras da arte, senhores da guerra. Curitiba: Editora CRV, 2011. p. 163-86.

GRAZIATO, V. P. P. Cerâmica kadiwéu processos, transformações, traduções: uma leitura do percurso da cerâmica kadiwéu do século XIX ao XXI. 2008. Dissertação (Mestrado em Poéticas Visuais) - Universidade de São Paulo, São Paulo, SP, 2008.

KOMIYAMA, C. B. P. A comercialização de cerâmica kadiwéu em Campo Grande, MS. 2015. Dissertação (Mestrado em Meio Ambiente e Desenvolvimento Regional) - Universidade Anhanguera-Uniderp, Campo Grande, MS, 2015.

LEVI-STRAUSS, C. Tristes trópicos. Tradução de Wilson Martins. São Paulo: Editôra Anhembi, 1957.

MARX, K. O capital: crítica da economia política. São Paulo: BOITEMPO, 2013. v. 1.

OLIVEIRA, R. C. Do índio ao bugre: o processo de assimilação dos terêna. Prefácio de Darcy Ribeiro. Rio de Janeiro: Francisco Alves, 1976.

OLIVEIRA, R. C. Urbanização e tribalismo: a integração dos índios terêna numa sociedade de classes. Rio de Janeiro: Zahar Editores, 1968.

PRADO, Francisco Rodrigues. História dos índios cavaleiros ou da nação guaicuru: 1795. Atualização e notas de Hildebrando Campestrini. Campo Grande: Instituto Histórico e Geográfico de Mato Grosso do Sul, 2006. (Série Relatos Históricos, 1).

RIBEIRO, B. G. Arte indígena, linguagem visual. São Paulo: USP, 1989. 
RIBEIRO, B. G. Dicionário do artesanato indígena. Belo Horizonte: USP, 1988.

RIBEIRO, D. Kadiwéu: ensaios etnológicos sobre o saber, o azar e a beleza. Petrópolis: Vozes, 1980.

SÁ, R. C.; INAGAKI, E. (Org.) Relatório parcial cerâmica kadiwéu: 2013/2014. Brasília: Museu do Índio/FUNAI, 2014.

SIQUEIRA JR., J. G. A iconografia kadiwéu Atual. In: VIDAL, L. (Org.). Grafismo indígena: estudos de antropologia estética. São Paulo: Studio Nobel/USP/FAPESP, 1992. p. 265-77.

SMITH, H. Do Rio de Janeiro a Cuiabá: notas de um naturalista. Cayeiras/São Paulo/Rio de Janeiro: Companhia Melhoramento S. Paulo, 1922.

\section{Sobre os autores:}

Gilberto Luiz Alves: É professor titular aposentado pela Universidade Federal de Mato Grosso do Sul. Atualmente é professor pesquisador do Programa de Pós-Graduação em Meio Ambiente e Desenvolvimento Regional na Universidade Anhanguera-Uniderp. E-mail: gilbertoalves9@uol.com.br, Orcid: https://orcid.org/0000-0001-9672-1459

Selma Maria Rodrigues: Doutoranda do Programa de Pós-Graduação em Meio Ambiente e Desenvolvimento Regional na Universidade AnhangueraUniderp. Atualmente é arquiteta. E-mail: selmamr8@gmail.com, Orcid: https://orcid.org/0000-0001-9117-2809

Recebido em: 15/05/2020

Aprovado para publicação em: 08/03/2021 